\title{
COMPARATIVE ASSESSMENT OF ALOE VERA JUICE AND $0.06 \%$ CHLORHEXIDINE ON CANDIDA ALBICANS PLAQUE
}

\author{
Shanty Chairani ${ }^{*}$ Sri W Rais ${ }^{*}$ Rani Purba*, Nabilah Nazalika*
}

\begin{tabular}{c} 
Keywords: \\
Aloe vera juice, \\
Candida albicans, \\
chlorhexidine, \\
plaque \\
\hline
\end{tabular}

\begin{abstract}
Background: Candida albicans is an opportunistic microorganism found in the oral cavity. High numbers of $\mathrm{C}$. Albicans were often detected in dental plaque from children with caries. Aloe vera contains active compounds such as anthraquinone and flavanoid that have an antifungal effect against $\mathrm{C}$. Albicans. The study aimed to compare the effect between Aloe vera juice and $0.06 \%$ chlorhexidine mouth rinse on C. Albicans colonies in plaque

Method: Experimental study consisted of 30 children with carious teeth $>4$. Subjects were divided into two groups; Aloe vera juice and chlorhexidine 0,06\%. Subjects were instructed to use $10 \mathrm{ml}$ of each mouthwash twice daily for 7 days. At baseline and 7thdays, dental plaque samples were collected and then inoculated on saboroud dextrose agar. C. Albicans colonies were counted and expressed in $\mathrm{CFU} / \mathrm{ml}$.
\end{abstract}

Result: The data were analyzed using a paired T-test and Mann-Whitney $U$ test. A significant reduction on $\mathrm{C}$. Albicans colonies in plaque was observed with Aloe vera juice $(p<0,05)$, which was not significantly different from the control group $(p>0,05)$. Conclusion: The present study suggested that Aloe vera juice can be used as a mouthwash due to its ability in reducing $\mathrm{C}$. Albicans in plaque.

\section{PENDAHULUAN}

Candida albicans merupakan mikroorganisme yang biasa ditemukan di rongga mulut, termasuk pada individu yang sehat. ${ }^{1}$ Candida albicans dapat hidup di bawah kondisi mikroaerofilik dan bahkan pada kondisi anaerob dengan rentang $\mathrm{pH}$ antara $2-8 .^{2}$ Candida albicans sering disebut memiliki sifat oportunistik karena dapat menjadi patogen serta mampu berinteraksi dengan bakteri di rongga mulut sehingga dapat menimbulkan penyakit, yang salah satunya adalah karies..$^{3,4}$

Karies gigi disebabkan oleh beberapa faktor utama seperti, host (keadaan gigi dan saliva), substrat (makanan), mikroorganisme, dan waktu. ${ }^{5}$ Mikroorganisme utama penyebab karies adalah Streptoccocus mutans dan Lactobacillus spp. 5,6 Namun, sejumlah penelitian melaporkan bahwa Candida albicans juga memiliki hubungan yang erat dengan karies. ${ }^{6,7}$ Klinke dkk.8 melaporkan bahwa Candida albicans dapat menjadi salah satu mikroorganisme penyebab karies karena mampu menoleransi dan membuat kondisi asam dengan memanfaatkan glukosa menghasilkan asam piruvat dan asam asetat yang dapat melarutkan hidroksiapatit pada gigi sehingga karies dapat terjadi. Falsetta dkk. ${ }^{9}$ melaporkan bahwa Candida albicans dan S. mutans memiliki hubungan mutualistik yang menyebabkan polisakarida ekstraseluler terbentuk semakin banyak pada plak sehingga koloni bakteri semakin meningkat. Penelitian Carvalho dkk. ${ }^{10}$ menunjukkan bahwa jumlah Candida albicans meningkat pada plak anak dengan jumlah karies $>4$.

Upaya yang dapat dilakukan untuk mencegah terjadinya karies adalah dengan mencegah dan menghilangkan akumulasi plak pada

* Program Studi Kedokteran Gigi Fakultas Kedokteran, Universitas Sriwijaya

Korespondensi: drg_shantychairani@yahoo.com 
gigi. ${ }^{11}$ Akumulasi plak pada gigi dapat dicegah dan dihilangkan secara mekanik dengan menyikat gigi teratur dan secara kimiawi dengan penggunaan obat kumur. ${ }^{12,13}$ Penggunaan obat kumur merupakan cara yang umum digunakan untuk mengontrol populasi Candida albicans di rongga mulut. Klorheksidin merupakan obat kumur utama (gold standard) yang menjadi pilihan di bidang kedokteran gigi dibandingkan dengan obat kumur lain karena memiliki efek antimikrobial berspektrum luas dengan banyak keuntungan terapeutik. ${ }^{12} \mathrm{Pe}$ nelitian yang dilakukan Paulone dkk. ${ }^{14}$ melaporkan bahwa klorheksidin 0,06\% signifikan menghambat pertumbuhan Candida albicans. Penelitian lain yang dilakukan Machado dkk. ${ }^{15}$ secara in vivo melaporkan bahwa klorheksidin 0,06\% signifikan mengurangi kolonisasi Candida albicans pada plak gigi. Klorheksidin tidak dapat digunakan dalam jangka waktu panjang karena memiliki banyak efek samping seperti rasanya yang tidak enak, dapat mengubah sensasi rasa, dan menyebabkan pewarnaan pada gigi. Untuk itu, perlu alternatif obat kumur lain yang sedikit memiliki efek samping namun memiliki efek yang sama. Lidah buaya merupakan bahan yang dapat dikembangkan sebagai obat kumur karena memiliki efek antimikrobial yang kuat, yang berasal dari senyawa aktif yang dikandungnya, seperti antrakuinon, saponin, dan flavonoid. ${ }^{16}$ Chairani dkk. ${ }^{17}$ melaporkan bahwa berkumur dengan jus lidah buaya selama 7 hari dapat menurunkan jumlah koloni Streptococcus mutans pada saliva anak dengan karies, sama efektifnya dengan penggunaan klorheksidin $0.06 \%$. Penelitian in vitro yang dilakukan Shireen dkk. ${ }^{18}$ menunjukkan bahwa ekstrak etanol lidah buaya secara signifikan mampu menghambat zona pertumbuhan Candida albicans. Kumar dkk. ${ }^{19}$ melaporkan bahwa penggunaan obat kumur lidah buaya konsentrasi $100 \%$ selama 4 hari terbukti sama efektif dengan obat kumur klorheksidin dalam mengurangi jumlah plak pada gigi. Penelitian ini bertujuan untuk membandingkan efektivitas antara berkumur jus lidah buaya dengan klorheksidin $0.06 \%$ terhadap jumlah koloni Candida albicans pada plak.

\section{METODE PENELITIAN}

\section{Persiapan subjek penelitian}

Jenis penelitian ini adalah penelitian eksperimental dengan rancangan pretest dan posttest with control group. Penelitian ini telah melalui uji kelayakan etik yang dilakukan oleh Komisi Etik Penelitian Rumah Sakit Umum Pusat Mohammad Hoesin Palembang dan Fakultas Kedokteran Universitas Sriwijaya dengan nomer sertifikat No. 97/kepkrsmhfkunsri/2017. Subjek penelitian berjumlah 30 orang yang merupakan siswa SD N 40 Palembang. Subjek diambil dengan teknik quota sampling. Kriteria inklusi dari subjek penelitian adalah berusia 6-12 tahun, memiliki karies gigi $>4$, dan bersedia mengikuti penelitian. Kriteria eksklusi pada penelitian ini adalah: menggunakan alat orthodonti dan gigi tiruan baik lepasan atau jaket,mengonsumsi obat-obatan yang dapat memengaruhi jumlah koloni Candida albicans dalam 3 bulan terakhir, memiliki riwayat sensitivitas terhadap lidah buaya atau obat kumur klorheksidin, dan memiliki riwayat penyakit sistemik. Subjek yang memenuhi kriteria inklusi dan eksklusi dijelaskan mengenai prosedur penelitian. Inform consent didapatkan dari orang tua atau wali dari subjek penelitian. Subjek dibagi secara acak menjadi dua kelompok; yaitu kelompok jus lidah buaya dan kelompok klorheksidin 0,06\%. Tiap subjek yang terlibat dalam penelitian diberikan sikat gigi, pasta gigi tanpa flouride, dan bahan kumur sesuai 
dengan kelompoknya masing-masing. Subjek diinstruksikan untuk menyikat giginya dengan teknik horizontal menggunakan sikat gigi dan pasta gigi yang telah diberikan. Penyikatan gigi dilakukan sebanyak dua kali sehari yaitu pagi setelah sarapan dan malam hari sebelum tidur. Setelah menyikat gigi, subjek diinstruksikan untuk berkumur dengan bahan kumur yang telah diberikan sebanyak $10 \mathrm{ml}$ selama 30 detik. Penggunaan obat kumur dilakukan selama 7 hari.

\section{Persiapan bahan kumur}

Lidah buaya yang digunakan pada penelitian ini berasal dari Badan Tanaman Pangan dan Hortikultura Provinsi Sumatera Selatan. Jus lidah buaya dibuat dengan cara daunnya dikupas dan dicuci bersih di bawah air mengalir untuk menghilangkan getahnya. Lidah buaya kemudian dipotong kecil-kecil dan diproses dengan blender hingga halus. Jus lidah buaya kemudian dimasukkan ke dalam botol kaca dan ditutup rapat. Obat kumur jus lidah buaya diberikan secara berkala, yaitu tiap dua hari sekali sehingga bahan kumur tetap segar dan tidak terdapat perubahan dalam bentuk rasa maupun warna. Obat kumur klorheksidin $0.06 \%$ didapatkan dengan cara mengencerkan klorheksidin 2\% (Gluco-CHeX) dengan akuades. Klorheksidin diencerkan agar rasanya tidak terlalu pahit bagi anak.

\section{Pengambilan Sampel Plak}

Pengambilan plak diakukan pada pagi hari. Subjek diinstruksikan untuk tidak makan dan minum selama \pm 1 jam sebelum pengambilan plak dilakukan. Pengambilan plak dilakukan sebelum intervensi dan setelah 7 hari penggunaan obat kumur. Saat pengambilan plak berlangsung, posisi subjek adalah duduk tegak dengan posisi kepala sedikit menengadah ke atas. Subjek diinstruksikan untuk membuka mulut, kemudian plak diambil menggunakan cotton swab steril pada gigi 16, 11, dan 26 di bagian labial/bukal serta pada gigi 36,31 , dan 46 di bagian lingual. Plak tersebut kemudian dimasukkan ke dalam tabung reaksi steril yang telah berisi larutan $\mathrm{NaCL} 0,9 \%$ sebanyak $3 \mathrm{ml}$, dan disimpan rapat dalam ice box untuk kemudian dibawa ke laboratorium. Plak lalu dibiakkan pada media Sabaroud dextrous agar dan diinkubasi pada suhu ruangan yaitu $25^{\circ} \mathrm{C}$ selama 3 hari. Pertumbuhan koloni Candida albicans dihitung dan dinyatakan dalam satuan Colony Forming Unit(CFU)/ml. Data yang didapat dilakukan uji normalitas Saphiro-Wilk untuk mengetahui sebaran data dan dianalisis menggunakan uji T berpasangan dan Mann-Whitney $U$ menggunakan SPSS 20.0.

\section{HASIL PENELITIAN}

Data penelitian ini telah dilakukan uji normalitas Shapiro-Wilk dan didapati bahwa seluruh data terdistribusi normal ( $p>0,05)$, kecuali data selisih sebelum dan setelah berkumur klorheksidin 0,06\%. Data dengan distribusi normal memenuhi syarat uji parametrik sehingga dilakukan uji T berpasangan. Data dengan distribusi tidak normal dianalisis menggunakan uji non-parametrik berupa uji Mann-Whitney $U$.

Tabel 1 menunjukkan bahwa setelah berkumur jus lidah buaya selama 7 hari terdapat penurunan jumlah koloni C. albicans pada plak. Hal yang sama juga ditunjukkan oleh kelompok yang berkumur dengan klorheksidin $0,06 \%$. Perbedaan jumlah koloni C. albicans pada plak antara sebelum dan sesudah berkumur pada kedua kelompok menunjukkan hasil yang signifikan $(p<0,05)$.

Uji Mann-Whitney $U$ dilakukan untuk mengetahui perbedaan rata-rata selisih jumlah koloni Candida albicans antara kedua kelompok. Tabel 2 menunjukkan bahwa rata-rata 
Tabel 1. Pengaruh berkumur jus lidah buaya terhadap jumlah koloni Candida albicans pada plak

Rata-rata jumlah koloni C. albicans \pm standar

\begin{tabular}{lccc}
\multicolumn{1}{c}{ Kelompok } & \multicolumn{2}{c}{ deviasi $(\mathrm{CFU} / \mathrm{ml})$} & P-value \\
\cline { 2 - 2 } & \multicolumn{2}{c}{ Sebelum berkumur } & Setelah berkumur \\
\hline Jus lidah buaya & $169,67 \pm 226,80$ & $18,80 \pm 28,82$ & $0,00^{*}$ \\
Klorheksidin & $161,80 \pm 177,40$ & $12,53 \pm 16,59$ & $0,00^{*}$ \\
$0,06 \%$ & & \\
\hline Keterangan: *Signifikan $(\mathrm{p}<0,05), \mathrm{Uji}$ T berpasangan,
\end{tabular}

Tabel 2. Perbedaan rata-rata selisih jumlah koloni Candida albicans antara kelompok berkumur jus lidah buaya dan klorheksidin $0,06 \%$

\begin{tabular}{lcc}
\hline \multicolumn{1}{c}{ Kelompok } & $\begin{array}{c}\text { Rata-rata selisih jumlah C. albicans } \pm \text { deviasi } \\
\text { standar (CFU/ml) }\end{array}$ & P-value \\
\hline Jus lidah buaya & $150,86 \pm 203,48$ & \multirow{2}{*}{0,46} \\
Klorheksidin 0,06\% & $149,27 \pm 162,55$ & \\
\hline
\end{tabular}

Keterangan: *Signifikan ( $p<0,05)$, uji Mann-Whitney U.

selisih jumlah koloni Candida albicans pada kelompok jus lidah buaya sedikit lebih tinggi dibandingkan dengan kelompok klorheksidin $0,06 \%$. Perbedaan tersebut dinyatakan tidak signifikan karena nilai $p>0,05$.

\section{DISKUSI}

Berdasarkan hasil penelitian, terlihat bahwa berkumur dengan jus lidah buaya selama 7 hari signifikan dalam menurunkan jumlah koloni Candida albicans pada plak. Hasil penelitian tersebut didukung dengan hasil penelitian sebelumnya yang dilakukan oleh Kumar dkk. ${ }^{19}$ yang melaporkan bahwa berkumur dengan jus lidah buaya $100 \%$ selama 4 hari efektif dalam mengurangi jumlah plak pada gigi. Hal tersebut disebabkan karena adanya efek antimikrobial yang dimiliki oleh tanaman lidah buaya. Menurut penelitian Das dkk. ${ }^{20}$ daun lidah buaya menunjukkan aktifitas antimikrobial yang tinggi terhadap Candida parapsilosis, Candida kruis dan Candida albicans, dengan masing-masing nilai IC50 (nilai hambat setengah minimal) adalah $252 \mu \mathrm{M}, 75,61 \mu \mathrm{M}$ dan $50,41 \mu \mathrm{M}$. Efek antimikrobial tersebut diketahui berasal dari bahan aktif yang terkandung dalam daun lidah buaya seperti: antrakuinon, flavonoid, saponin, dan lignin. ${ }^{19,20}$ Kandungan tersebut dapat melarutkan lipid pada membran mikroorganisme (lipoprotein) sehingga mengganggu fungsi sel dan merusak membran sel mikroorganisme. Kandungan lainnya seperti mannan, glukomanan, dan acemannan, yang terdapat pada lidah buaya juga dapat berperan sebagai imunomodulator sehingga meningkatkan pertahanan tubuh host terhadap antigen dari jamur. ${ }^{20,21}$

Penggunaan bahan kumur klorheksidin 0,06\% juga menunjukkan penurunan jumlah koloni Candida albicans pada plak yang signifikan. Hal tersebut sejalan dengan penelitian in vitro yang dilakukan oleh Paulone dkk. ${ }^{14}$ yang melaporkan bahwa klorheksidin 0,06\% signifikan menghambat pertumbuhan Candida albicans. Penelitian lain yang juga mendukung 
hasil tersebut adalah dari Machado dkk. ${ }^{15}$ secara in vivo melaporkan bahwa klorheksidin 0,06\% signifikan mengurangi kolonisasi Candida albicans pada plak gigi. Mekanisme aksi dari klorheksidin terhadap sel jamur terkait dengan adanya ikatan antara rantai molekul bikationik dari bis-guanida klorheksidin dengan fosfolipid dan protein yang ada pada dinding sel jamur yang menyebabkan pengurangan permeabilitas membran sitoplasma sehingga aktifitas osmoregulasi dan metabolisme dari sel jamur terganggu. ${ }^{15,22,23}$ Apabila konsentrasi klorheksidin ditingkatkan, maka interaksi yang terbentuk antara rantai molekul klorheksidin dan sel jamur akan semakin kuat, menyebabkan terganggunya aktifitas membran plasma sehingga jamur lama-kelamaan akan mati. ${ }^{23}$ Hanya saja bila konsentrasi klorheksidin semakin besar., rasanya menjadi semakin pahit dan kurang bisa ditoleran oleh anak. Efek samping lain dari klorheksidin seperti menyebabkan pewarnaan gigi dan menurunkan sensasi rasa juga perlu diperhatikan.

Jumlah rata-rata selisih koloni Candida albicans setelah berkumur jus lidah buaya lebih tinggi dibandingkan dengan klorheksidin 0,06\% dengan nilai perbedaan yang tidak signifikan. Hasil tersebut didukung oleh penelitian in vitro yang dilakukan oleh Jeevitha dkk. ${ }^{24}$ yang melaporkan bahwa zona hambat Candida albicans untuk obat kumur yang mengandung ekstrak lidah buaya dan obat kumur klorheksidin $0,2 \%$ memiliki nilai perbedaan yang tidak signifikan. Penelitian in vivo yang dilakukan oleh Abduljabbar dkk. ${ }^{25}$ menunjukkan bahwa ekstrak alkohol lidah buaya efektif menurunkan jumlah koloni Candida albicans pada plat gigi tiruan, sama halnya dengan klorheksidin $2 \%$, dengan nilai perbedaan yang tidak signifikan. Penelitian lain yang membandingkan ekstrak lidah buaya secara in vitro dengan obat anti jamur juga telah dilakukan oleh Shireen dkk. ${ }^{21}$ Penelitian tersebut melaporkan bahwa ekstrak etanol lidah buaya pada konsentrasi 250 $\mu \mathrm{g}$ telah mampu menghambat pertumbuhan Candida albicans dan hampir sama efeknya dengan obat anti jamur ampoterisin B pada konsentrasi $1000 \mu \mathrm{g}$. Oleh sebab itu, penelitian klinis lebih lanjut mengenai jus lidah buaya yang dibandingkan dengan obat jamur seperti nistatin dan flukonazol pada Candida albicans perlu dilakukan.

Hasil penelitian menunjukkan bahwa jus lidah buaya memiliki efek yang sama dengan klorheksidin terhadap Candida albicans sehingga dapat dijadikan sebagai obat kumur alternatif yang dapat dimanfaatkan dalam kehidupan sehari-hari. Bahan baku pembuatan jus lidah buaya yang alami menjadikannya lebih praktis dan ekonomis untuk digunakan, dibandingkan dengan obat kumur komersial. Kekurangan yang dimiliki oleh bahan kumur jus lidah buaya adalah dapat mengalami perubahan rasa setelah disimpan selama 3-4 hari. Pengembangan formulasi pembuatan jus lidah buaya perlu diteliti lebih lanjut agar didapati jus lidah buaya yang lebih tahan lama tanpa mengurangi manfaatnya.

\section{KESIMPULAN}

Kesimpulan dari penelitian ini adalah berkumur dengan jus lidah buaya dapat menurunkan jumlah koloni Candida albicans pada plak, dengan efek yang sama dengan klorheksidin $0,06 \%$.

\section{DAFTAR PUSTAKA}

1. Rozkiewicz D, Daniluk T, Zaremba ML, Cylwik-Rikicka D, Stokowska W, Pawinska M, et al. Oral Candida albicans carriage in healthy preschool and school children. Adv Med Sci; 2006. 51(4): 187-90. 
2. Arora DK, Khachatourians GG. Fungal genomics. USA: Elsevier; 2014. p. 99.

3. Montelongo-Jauregui D, Lopez-Ribot JL. Candida interactions with the oral bacterial microbiota. J Fungi. 2018;4(4):122. doi:10.3390/jof4040122.

4. Janus MM, Crielaard W, Volgenant CMC, van der Veen MH, Brandt BW, Krom BP. Candida albicans alters the bacterial microbiome of early in vitro oral biofilms. J Oral Microbiol. 2017; 9(1): 1270613. Published online 2017 Jan 23. doi: 10.1080/20002297.2016.1270613

5. Meyer-Lueckel H, Paris S, Ekstrand KR. Caries management-science and clinical practice. USA: Thieme; 2013. p. v, 10-8, 22-30.

6. Metwalli KH, Krom BP, Khan SA, Jabra-rizk MA. Streptococcus mutans, Candida albicans, and the human mouth: sticky situation. PLOS. 2013; 9(10).1008-14

7. Binita S, Hind PB, Visuja C, Archana A, Ashish KS, Gupta N. Comparative evaluation of oral Candida albicans carriage in children with and without dental caries: A microbiological in vivo study. Int J Clin Pediatr Dent. 2012;5(2):108-12.

8. Klinke T, Guggenhein B, Klimm W, Thurnheer T. Dental caries in rats associated with Candida albicans. Caries Res. 2011; 45(6):100-6.

9. Falsetta ML, Klein MI, Colonne PM, Scott-Anne $\mathrm{K}$, Gregoire S, Pai CH, et al. Symbiotic relationship between Streptococcus mutans and Candida albicans synergizes virulence of plaque biofilms in vivo. Infect Immun. 2014; 82(5): 1968-81.

10. Carvalho FG, Parisotto TM, Hebling J, Spolidorio DMP. Presence of Candida spp. in infants oral cavity and its association with ECC. Braz J Oral Sci. 2007; 6(20): 1249-53.

11. Edelstein $\mathrm{BL}$, Chinn $\mathrm{CH}$. Update on disparities in oral health and access to dental care for America's children. Acad Pediatr. 2009; 9(6): 415-9.

12. Sicca C, Bobbio E, Quartuccio N, Nicolo G, Cistaro A. Preventive of dental caries: a review of effective treatment. J Clin Exp Dent. 2016; 8(5): 604-10.

13. Rahul M, Shobha T, Monika R, Molay B. Antimicrobial efficacy of probiotic and herbal oral rinses against Candida albicans in children: a randomized clinical trial. JP Journal. 2016; 9(1): 25-30.

14. Paulone S, Malavasi G, Ardizzoni A, Orsi CF, Peppoloni S, Neglia RG, et al. Candda albicans survival, growth, and biofilm formation are differently affected by mouthwash: an in vitro study. EDIMES. 2017; 40(1): 45-52.

15. Machado FC, Portela MB, Cunha AC, Souza IPR, Soares RMA, Castro GFBA. Antifungal activity of chlorhexidine on Candida sp. Rev Odontol UNESP. 2010; 39(5): 271-5.

16. Rajeswari R, Umadevi M. Aloe vera: The miracle plant its medicinal and traditional uses in India. Pytojournal. 2012; 1(4): 118-24.

17. Chairani S, Rais SW, Purba R, Nazalika N. Perbandingan efektifitas jus lidah buaya dan klorhexidin $0.06 \%$ terhadap jumlah koloni Strepto- coccus mutans saliva. Odonto Dental Journal. 2018; 5(1): 54-9.

18. Shireen F, Manipal S, Prabu D. Anti-fungal activity of Aloe vera: in vitro study. SRM Journal of Research in Dental Sciences. 2015; 6(2): 92-5.

19. Kumar GR, Devanand G, John DG, Ankit Y, Khursheed $O$, Sumit M. Preliminary antiplaque efficacy of Aloe vera mouthwash on 4 day plaque re-growth model: randomized control trial. Ethiop J Health Sci. 2014; 24(2):139-44.

20. Das P, Srivastav AK. Isolation and characterization of novel protein with antifungal and anti-inflammatory properties from Aloe vera leaf gel. Elsevier. 2010; 4(6): 658-61.

21. Farahnejad Z1, Ghazanfari T, Yaraee R. Immunomodulatory effects of Aloe vera and its fractions on response of macrophages against Candida albicans. Immunopharmacol Immunotoxicol. 2011;33(4):676-81.

22. Mathur S, Mathur T, Srivastava R, Khatri R. Chlorhexidine: The gold standard in chemical plaque control. National Journal of Physiology, Pharmacy \& Pharmacology. 2011; 1(2): 45-50.

23. Fathilah AR, Himratul-Aznita WH, Fatheen AR, Suriani KR. The antifungal properties of chlorhexidine digluconate and cetylpyrinidinium chloride on oral Candida. J Dent. 2012; 40(7): 60915.

24. Jeevitha T, Deepa K, Michael A. In vitro evaluation of antimicrobial activity of chemical and Aloe vera mouthwases againts Candida albicans. WJPR. 2015; 4(8): 1829-38.

25. Abduljabbar MA, Ali EHA, Kamil NB, Al-Kahayyat FNMT. Effect of olea extracts on oral candida in patients wearing dentures of different base materials. Dental Sci. 2016; 1(1): 1-15. 